\title{
TEACHING CHARACTER THROUGH ORAL STORIES IN INDONESIA AND MALAYSIA
}

\author{
Silvia Rosa \\ Department of Letters, Faculty of Humanities \\ Andalas University, Padang, Indonesia \\ (sylvie_rosha@ymail.com, silviarosa@hum.unand.ac.id) \\ DOI: https://doi.org/10.22452/jati.vol24no2.10
}

\begin{abstract}
A nation's character is formed from its human capital, the character of its individuals. Character is abstract, nature of changes to character is challenging to monitor, but it can be felt. The formation of individual character can be facilitated through art, including literature. Folk stories are one literary genre that can be used to develop character, especially in children's education. Folk stories can be used as a medium to instil educational values in children. The tradition of storytelling has long been used in children's education in Indonesia and Malaysia. However, when the community changes rapidly due to the process of modernisation and even globalisation, the telling of traditional stories to children in educational practice becomes less widely embraced. Various types of games, based on digital technology, have marginalised the tradition of storytelling. Folklore contains moral, religious, educational messages that cannot be replaced by digital games. The consequence of this abandonment of traditional storytelling means disadvantaging the world of children's education, especially in character education. The richness of the message, the characterforming value found in a diverse range of folklore can be used for teaching children and the younger generation of a nation. This article discusses two folktales from two neighbouring countries, namely Indonesia and Malaysia. The two stories are titled "Batu Ajuang Batu Peti" from the Province of West Sumatra, Indonesia and "Si Tanggang" from Malaysia. Both of these stories have powerful messages that are very suitable to be told to children and the younger generation to form the character of the younger generation in both nations.
\end{abstract}

Keywords: characters, literature, folklore, Indonesia, Malaysia

\section{Introduction}

Teaching character is an essential pillar in forming the moral fibre of the Indonesian nation. All levels of education in Indonesia, ranging from early age 
education, elementary school level, junior high school and senior high school have prepared character teaching strategies for their students. The same thing has happened in America (Nucci, 2014: 48-49); Korea (Nucci, 2014: 326); and also China (Nucci, 2014: 401). However, the method of character education carried out in Indonesia is not stimulating, because it is delivered through manual teaching, delivered in lectures, and without being interspersed with methods that are artistic and inspire the imagination. It is essential to design character teaching methods that can tailor to the vision and mission of educational institutions as the managers of the educational process for the younger generation (Kamaruddin, 2012). The delivery of education in formal schools in Indonesia certainly cannot ignore the vision and mission of the implementation of a national education system that must take place and be planned consciously. It is to ensure that a pleasant learning atmosphere to be realised so that students can develop their potential in building spiritual strength, self-control, personality and intelligence, good character, and the skills needed for the individual, society, and the nation (UU Sisdiknas, 2003 - Law of the Republic of Indonesia Number 20 of 2003 "National Education System"). In order for the vision and mission to accomplish, a strategy that is suitable and interesting for students, who are the target of education, is needed. Art can be an alternative pathway in character teaching strategies for informal schools in Indonesia. Through art, character sensitivity will become well-honed, smooth, sensitive, and pleasant. This article argues that the use of literary art is one of the critical strategies for teaching character to students in formal schools.

Etymologically, the term 'character' in English has a close meaning with the term character (budi pekerti) in the Indonesian language. The Indonesian word for character comprises two essential words, namely mind (budi) and character (pekerti). The term mind has the nuance of an inner instrument that can be a guide to reason and feeling in weighing up good or bad values, while the word character means behaviour, temperament, and morals. So, the term character can be interpreted as a fundamental tool in controlling behaviour (KBBI, 2010: 170). The term character comes from various aspects, such as religion, state regulations, societal norms, philosophical teachings, and also art. Elfrianto (2015) states that behaviour is related to words and actions that are base on values, norms both from religious teachings and customs that apply in a particular place and community. This article discusses art as one of the sources for forming character.

Art consists of many branches, such as music, sculpture, painting, dance, literary arts, and others. Each branch of art has its distinct material and orientation, although the effects it produces are both aesthetic and creative works-oriented. The beauty produced by each artwork from different branches 
creates different impressions and feelings. Literary art is one branch oriented towards writings that use the medium of language, which can be beautiful, imaginative and creative in its use. The aesthetic aspect comes from using a style that creates the effect of beauty and connotative meanings. It is said that literary art encompasses beautiful writings, but literary art can be sourced from oral forms. The criteria can characterise literary art for using distinctive language as the material for its creation.

Literary art consists of three genres, namely poetry, prose, and drama. Poetry is the oldest literary genre. It is said to be the oldest because in the history of Indonesian literature the form of early (classical) literature in Indonesia was found in the form of pantun, syair, talibun, seloka, gurindam, pepatah, petitih, mamangan, bidal and so on which are grouped into the genre of poetry. In each region in Indonesia forms are found that are similar but with different names such as sinrilik (Lewa, 2015); geguritan (Herawan, 2017); umpasa (Sinaga, 2016) and so on. The prose is a literary genre that continues the tradition of the genre of poetry but in the form of a narrative pattern. Great poetry forms, such as those found in Minangkabau society, are called lyrical prose. Lyrical prose in Minangkabau society is the raw material that builds a kaba. It is a form of prose that is well known in the Minangkabau community literature in West Sumatra. Initial form of this $k a b a$ is verbal, delivered by a speaker in front of an audience (Djamaris, 2002); and lasts overnight, and has no time limits (Balckwood, 2001); Junus (1994). Then, after written literature began to become established in the Minangkabau society, kaba began to be written as well. Writing kaba is done by using Jawi letters which are in Arabic and the Malay language. This Jawi script is often also referred to as Malay Arabic letters by Minangkabau people. Malaysia has also used Jawi letters in the history of its civilisation (Salehuddin, 2012).

The characteristics of the prose genre are narrative, thematic, and contain stories of storytelling, which come to life through its characters and characterisations. Folk stories are one part of the prose genre. The last literary genre is drama, which has more distinctive and specific characteristics. Its characteristics are specified by the presence of a series of dialogues that are a medium for the delivery of thoughts and feelings of the author. The characters in the story deliver a series of dialogues. The story's characters are in charge of moving the plot and storyline in the drama genre. The drama genre began to develop in Indonesia at the time of Western influences began marked by the emergence of theatre in several places, especially in cultural centres.

Wellek (1989: 14-15) states that language is the raw material for literature, such as stone and copper for sculpture, paint for painting, and sound for the art of music. Language as a raw material for literature is not an inanimate object but 
has a cultural and linguistic content from the group of users of that language. The literary language contains ambiguity and homonyms and has irregular and irrational categories. Besides that, literary language also contains associations, connotative, not just mere referential language. Literary language has expressive functions, showing the tone and attitude of the speaker or writer. Based on the Wellek ideas, it can be stated that through literature, in which the medium is language, thought patterns, attitudes and values can be identified with its literary community. That is literature contains the structure of thinking of the community of creators and supporters of the literary work. This happens indeed and applies to countries with related cultures such as Indonesia and Malaysia.

Indonesia and Malaysia have relationships often referred to as allied countries. The closeness of the relations between the two countries was forge since both countries were preparing for independence. The typical fate of colonised countries united the spirit of the two nations to help each other. This bond of a shared fate is also reflected in the significant influence of Indonesian thinkers in Malaysia, ranging from Islamic thinkers to nationalists (Hara, 2015). Evidence of a real kinship is manifested in the form of sympathy in fighting the colonists. In Malaysia, a group formed, initiated by Burhanuddin Al Helmy, Ibrahim Yakoob, Ahmad Boestaman, Mokhtaruddin Lasso, and in Indonesia Muhammad Yamin, Mohammad Hatta and Sukarno who talked about the form of cooperation between their country. Although each group proposed different names, namely Malay Raya, Indonesia Raya and later Nusantara, behind this, there was an assumption that they were allied (Liow 2004: 23). The term Malay world illustrates this kinship's closeness. At least, there has been a common aspiration in this group of allied Malays (Hara, 2015).

So it shows how close the relationship has been between Indonesia and Malaysia since a long time ago, even though in the middle of the journey, there were quarrels that disrupted the relations of the two countries. At the very least, art will be a way of meeting that can reassure relations between the two countries. Therefore, art does not divide, but art can unite two parties which are far apart, including Indonesia and Malaysia. Especially when there are already so many Indonesians living in Malaysia, and conversely there are already very many Malaysians living in Indonesia. Whatever the conditions are now, it cannot be denied in fact, the allied feeling is still developing in the hearts of the people of Indonesia and Malaysia. Especially if art always acts as a glue, which includes literature. Through literary art, refinement of character will always be created in the hearts of the two allied nations. Indonesia and Malaysia will remain related, together with the intermingling of the arts and culture of the two countries. Many Indonesians live in Malaysia, and vice versa. The mixture has led to a 
mixed literary repertoire in both countries. It certainly will not be difficult if literary art is used as a medium for the formation of national character in the younger generations in the two allied countries.

\section{Literature review}

Ethics are taught through three models in the history of education in Indonesia, namely as a model of independent subjects, incorporation with other subjects, and integrated with other subjects (Sutjipto, 2014). The latest curriculum, namely the 2013 curriculum is applied in Indonesia, applies the third model, which is integrating it into other subjects. Character teaching can also take advantage of literature. Literary art is one branch of art that utilises language as the medium of delivery. Language in literature is flexible, aesthetic and ideological at the same time. Literary art can be a means of conveying ideas, norms about something that is of good and evil, value as well as philosophical values that are useful in mental and personality development. It is possible that literature functions as dulce et utile, entertaining and, at the same time, beneficial. Luxemburg (1984) defines literature as a creation, not merely imitation. The author created a new world as a continuation of the creation process in the universe and even perfected it. It means that through literature, the act of creating and even perfecting imperfect events can be enacted in the universe. Through literature, an ideal dream world can be constructed, which could be a role model in real life. Besides being a role model, literature also opens space to criticise things that are not good that occur in humans and their environment. Therefore there are enough literary studies available, especially those related to the formation of personality and attitude. Some of them related to folklore. These studies include those by Rosa (2017), Gayatri (2017), and Suhartono et al. (2010).

\section{Methodology}

The method used for this study is a comparative literature research method. The sources of research data are two folk stories. The first folk story comes from Indonesia. Story collection was done through audio recording techniques. The first recorded folk story was done in West Sumatra. The second folk story comes from Malaysia. This second story is taken from library data. Si Tanggang's story was examined by Suwartini (2018); Radzi (2015); and Ismail (2015). The two folk stories discussed in this article are titled "Batu Ajuang Batu Peti" from West Sumatra. The other Malaysian folk tale is titled "Si Tanggang". Both of this folklore was chosen as material objects of research because they both have the theme of sanctioning the pronunciation of sworn words when someone wants to 
instil the power of truth in his words. The tendency of swearing as a strategy to prove the truth of a character's words is a method found in folklore. Thematically, these two stories are important to remind that it is not suitable for humans to swear too quickly, especially when the oath is don for things that are not true. Messages like this are essential to convey in children's character education. The decision to choose folklore with the theme of the tendency to take an oath is the reason for choosing this two folklore to be material objects of this research. This paper discusses the opportunity to use folklore as a media for forming national character in both allied countries.

\section{Results}

\section{Findings and Analysis}

There are two stories discussed in this article. These two stories are critical as a character education tool for the younger generation. This story is best presented orally to young people at an early age, even those who are already teenagers. The educational values can be found in the plot and behaviour of the story characters, from which character education can be taught. The following is a synopsis of the two stories, which is the material object in this study.

\section{Synopsis of "Batu Ajuang Batu Peti"}

The story of Batu Ajuang Batu Peti tells the story of a beautiful princess. Her beauty is famous throughout the country. Her father was a king in Bukit Perasapan. Many young people in the village were attracted to the princess. However, the young men did not dare to propose to the princess because of the striking differences in social status. The girl was the only child of a wealthy king. Suitors are constrained by the belief that they must be the son of a king as there would be no way for the king's daughter to be married to a commoner. Such a view became an obstacle for young people in the country to propose marriage to the daughter of the King of Bukit Perasapan.

One day, a Portuguese merchant heard the news about the beauty of the King of Bukit Perasapan's daughter. The merchant, Mr Hendrikheard the news about the beauty of the princess from his bodyguards who urged their master to propose to the princess to become his wife. Initially, Mr Hendrik was not very interested. However, after being pressured by his two men, he began to be interested and intend to propose to the king's daughter. Mr Hendrik came to visit the king's palace Evidence of his sincerity was evidenced by his offer of a gold chest. Two bodyguards accompanied him. Mr Hendrik intended to propose to the king's daughter by giving the gold chest as proof of his love for the king's daughter. However, the King of Bukit Perasapan was wise and kind-hearted. The 
king welcomed Mr Hendrik to his palace with a happy heart and friendly attitude. The friendliness and kindness of the King of Bukit Perasapan made $\mathrm{Mr}$ Hendrik even more determined to achieve the purpose of his visit to the palace. Mr Hendrik also expressed his intention to propose to the King of Bukit Perasapan's daughter.

To win the hand of the King's daughter, Mr Hendrik claimed that he was the son of a king in Portugal. The King of Bukit Perasapan did not readily believe Mr Hendrik. Mr Hendrik vowed he would convince the King of Bukit Perasapan that he was indeed a son of the king in Portugal. To strengthen his claim, $\mathrm{Mr}$ Hendrik stated, he was willing to accept sanctions if he was not right. $\mathrm{Mr}$ Hendrik vowed that he was ready to turn to stone if found to be lying. The King of Bukit Perasapan did not immediately believe Mr Hendrik, but also did not immediately reject Mr Hendrik's proposal. Wisely, the King of Bukit Perasapan gave Mr Hendrik three months to prove the truth of his claim. If for three full moons, nothing happened to Mr Hendrik due to the claim he had made, then the King of Bukit Perasapan would receive Mr Hendrik's proposal for the hand of his only daughter.

Three full months passed for Mr Hendrik without any incident caused by his claim. So with a happy feeling, Mr Hendrik set about to return to Bukit Perasapan kingdom. This time he felt powerful and was sure he would succeed in marrying the King of Bukit Perasapan's daughter. Mr Hendrik decided to sail back across the ocean to Bukit Perasapan kingdom accompanied by his bodyguards. With a feeling of happiness, he also crossed the open ocean towards the kingdom of Bukit Perasapan, however, misfortune can not be avoided. While at sea, strong winds blew and a big storm caused damage to his ship. The ship was a Portuguese merchant vessel, and the storm hit his entire crew. Their ship was broken up by big waves and wrecked near a beach. Mr Hendrik and the ship and everything on it then turned into stone. He had consumed his claim of being a king's son in Portugal. The incident proved that Mr Hendrik had lied to the King of Bukit Perasapan. Mr Hendrik was not the son of a king in Portugal. His desire to win the king's daughter and inherit the kingdom had blinded Mr Hendrik, even making him willing to lie. Finally, Mr Hendrik was punished due to his falsehood.

\section{Synopsis of "Si Tanggang"}

The story of Tanggang is about a boy whose parents are Talang and Deruma. Talang's household is poor. However, their only son named Tanggang wanted to be a successful person and have lots of money. One day, Tanggang saw a large ship docked in a port near his village. He begged the ship's captain to be allowed 
to sail with the ship employed as a crew member. The captain of the ship agreed to the request. After gaining permission from his parents, Tanggang departed on the ship. Tanggang's departure left a deep feeling of sadness for his parents. His father and mother felt very dejected to be part of their child. Tanggang promised to return to his hometown later if he became rich. His father and mother cried at Tanggang's departure.

While sailing on the big boat, Tanggang showed himself to be diligent and smart in his work. The ship captain was delighted to see the craft owned by Tanggang. The ship's captain made Tanggang his adopted son. Finally, the captain of the ship grew old and could no longer work. Tanggang was entrusted by his foster father to become the new captain of the ship. Tanggang's hard work and skill produced excellent results. Tanggang became rich because of his success in trading, and he was now called Captain Tanggang. The success of Tanggang had prompted the Sultan to invite Captain Tanggang to the palace. The Sultan intended to marry Tanggang to his daughter. Tanggang did not accept the Sultan's plan. Finally, Tanggang and the beautiful princess of the Sultan married. The happiness and wealth of those present doubled.

One day Tanggang decided to bring his wife on a voyage. The purpose of the voyage is to travel to Tanggang's hometown. So, Tanggang and his wife departed, accompanied by guards and crew members. They went sailing on a large ship that was used by Tanggang for a business and not long after Tanggang's ship arrived at the river mouth located not far from his hometown. Talang and his now old and ill wife, Derumaheard the news that, at the mouth of the river, there was a large ship at anchor. The two parents, feeling both anxious and happy, rushed to visit the river estuary to see a docked ship. How happy were the hearts of the two older people to see that on the steps of the ship stood a couple, one very handsome man and a beautiful woman? Deruma could not wait to get up and get on the boat. She was very sure that the one standing at the door of the ship was her son Tanggang. She was impatient to hug her son, whom she had long missed. The two older people hobbled up the ship's stairs but were immediately intercepted by the crew who were guarding the front of the stairs. After listening to the parents' confession, the crew went to ask Captain Tanggang, who was standing at the door of the ship with his wife.

Tanggang did not want to acknowledge to the crew that the two older people were his father and mother. Especially after hearing the question of his wife, who was astonished to see the two parents. Tanggang was embarrassed increasingly to acknowledge to his wife that the two were his father and mother. Tanggang ordered the crew to prevent the two from boarding the ship. Tanggang did not allow the two to board the ship to meet him and his wife. 
Tanggang lied to his wife that his father and mother had died. Tanggang did not want to confess to his wife that his parents were still alive and indeed still in the village. Tanggang was ashamed to admit to his wife of his origins and his poor parents. Therefore, Tanggang chose not to meet his parents, who were adamant about going up the ship's ladder. The crew continued to forbid the parents from going up the ship's stairs, although the parents insisted on going aboard to meet their son and daughter-in-law. They want to meet and hug their children. Deruma and Talang came to the ship to release the longing they had endured for decades. The arrival of the two older people also brought a dried banana, Tanggang's favourite. However, Tanggang denied the fact that those old and poor people were his father and mother.

The parents were sad and cried after being refused entry by Tanggang to his ship. They left the ship with a deep feeling of sorrow. His mother cried because she was sad and disappointed over the changes in her beloved child's attitude. Without feeling, she looked up to the sky and begged God for help to show proof that she was Tanggang's mother. Suddenly a strong wind blew, and lightning struck. Instantly a storm raged at sea. Tanggang's ship was tossed. Finally, the ship turned upside down and sank. God granted the prayer of Tanggang's mother to prove the truth that Deruma was Tanggang's mother. Suddenly Tanggang realised that the shipwreck was the result of God listening to his mother's prayer. Tanggang shouted for forgiveness to his mother, but it was too late, God did not want to forgive Tanggang, who was punished for his cruelty to his mother. Tanggang'ship and all its contents sank into the ocean, including himself and his wife. As soon as the ship sank, it turned into stone, Likewise, Tanggang and his wife.

Both folklore has plots that are similar to the distribution of useful moral content, which is not much different. The following table 1 shows these conditions.

Table 1: Comparison of Plots and Moral Content

\begin{tabular}{|c|c|c|}
\hline & Batu Ajuang Batu Peti & Si Tanggang \\
\hline Plot & $\begin{array}{l}\text { 1. Princess King Bukit, a beautiful } \\
\text { and vibrant couple. } \\
2 \text { Courted by a Portuguese } \\
\text { merchant who claimed to be a } \\
\text { king's son. } \\
\text { 3. False claim to support the } \\
\text { Character's character. }\end{array}$ & $\begin{array}{l}\text { 1. The poor and unlucky youth. } \\
\text { 2. Sailing and trekking } \\
\text { 3. Parent seek God's help because of } \\
\text { Disappointment } \\
\text { 4. Tanggang punished? }\end{array}$ \\
\hline Moral & $\begin{array}{l}\text { 1. Should not be interested } \\
\text { because of physical }\end{array}$ & $\begin{array}{l}\text { 1. Not to be ashamed of being poor } \\
\text { 2. The spirit of self-improvement }\end{array}$ \\
\hline
\end{tabular}




\begin{tabular}{|l|l|l|}
\hline & $\begin{array}{l}\text { 2. Cannot be greedy } \\
\text { 3. Cannot lie }\end{array}$ & $\begin{array}{l}\text { and luck } \\
\text { 4. May not make false claims not be arrogant with } \\
\text { 5. Can not swear falsehoods }\end{array}$ \\
& $\begin{array}{l}\text { wealth } \\
\text { 4. Can not be rebellious } \\
\text { 5. Can not swear } \\
\text { 6. Oath will reap woe }\end{array}$ \\
\hline
\end{tabular}

\section{Discussion}

This study finds that the folk stories from both countries have value as material for teaching to build good character. The first story "Batu Ajuang Batu Peti" contains the value of honesty. Honesty is an essential capital of life. Whatever worldly wants dominates human personality, yet honesty can not be at stake. $\mathrm{Mr}$ Hendrik risked for being discovered for dishonesty in his proposal to the royal princess. He willingly lied and claimed that he was a prince in Portugal. $\mathrm{Mr}$ Hendrik is merely an ordinary merchant who does business over the continent, trading on ships for months. He desired to win the hand of a beautiful girl, who is a princess of a king, which would enable Mr Hendrik to get the royal legacy of the King of Bukit Perasapan. He lied to the king of the Bukit Perasapan to get the woman and the throne he wanted.

This mentality is evil in life. Moreover lying is accompanied by swearing to make other people believe in the truth of the words. People who readily swear falsehoods are people who will be persecuted in their lives in this world and will pay for their sins in the afterlife. This view is evident in the folklore of "Batu Ajuang Batu Peti" from West Sumatra. Mr Hendrik bears the wages of sin in the world through the wrecking of the ship and all its contents, including himself. The sin of lying not only gets punished in the physical world but also the hereafter. This message or message carried by the story of "Batu Ajuang Batu Peti" is a message commonly found in the lives of people who adhere to religious beliefs. The majority of the people of West Sumatra are Muslim. The messages contained in these folk stories are the virtue of honesty that is in line with the concept of honesty in Islam.

The second story, "Si Tanggang", contains values of politeness, humbleness, obedience to parents. Values such as these are fundamental in the formation of character in a child and even in an adult. If each individual becomes familiar with folk stories such as this, psychologically it will affect the formation of the personality. Those who have often listened to similar stories will undoubtedly be affected by the teachings about the character embodied in this folk tale. Through "Si Tanggang" it teaches how hard work can change fate. The story "Si Tanggang" also teaches about not being arrogant and forgetful. The most critical value contained in Si Tanggang's story is not to be ashamed to see 
parental poverty, let alone deny that they are not our parents. The teaching of not to being disrespectful to parents is a common and vital value of character taught in Malay society, as found in Indonesia and Malaysia. The issue of the value of respect for both parents found in the story of "Si Tanggang", also immediately implies a religious value that becomes a guide within this folklore. The Malay community is not much different from the Minangkabau people in West Sumatra. Both groups are devout Muslims. Therefore, it is not surprising, and there are messages with nuances of Islamic religion in folktales from both countries.

Thus, it can be stated that if the appreciation and socialisation of folklore narrative are carried out widely in a community group and even across the state, institutionalised through community literacy movements, it will undoubtedly result in the formation of good character and courtesy. This strategy can be an antidote to the radical movements that have developed rapidly in society lately. Whatever has been shown in that folklore has a subtle way of forming character. The subtlety and beauty contained in folklore is the cause because folklore is a literary work. Literary works can teach something of value or ideology in a veiled way, without being felt by the reader. It is not evident that actually, the author or storyteller is teaching something to the reader or listener of the story. People who love to read and hear literary works will unwittingly experience an influence on their soul and mind in looking at the world around them. Their feelings will become more sensitive and subtle in addressing the problems in the world around him. They will be more sensitive, responsive in responding to injustice, savagery, dishonesty and other negative values that occur in the community. With this attitude of sensitivity and responsiveness is found a high potential for building the character of the nation, not least in the Indonesian and Malaysian nations.

Based on the findings and results obtained from the research conducted on the material objects in this article, namely the folklore of "Batu Ajuang Batu Peti" and "Si Tanggang", it can be seen that folklore contains values which can be used for character education of the young in both countries. It is possible because actually, literature (folklore) is a teaching tool delivered in disguise. Literary works that use the medium of language, namely beautiful language enchants the reader to continue reading, listening and enjoying the stories. Though behind the stories conveyed are the message and the values that are important for guidance. 


\section{Conclusion}

At present, the Indonesian state is actively working on community literacy programs - both in the formal sector and in the non-formal sector. In the formal sector, through educational institutions, from early childhood education to high school education. On the other hand, in the non-formal sector, many people have created their libraries along with mobile libraries that offer books to the public. The reading and writing movement is carried out in schools every day. The reading material consists of non-fiction and fiction books. Non-fiction books, of course, relates to the subjects studied in a class. While those related to fiction, are the stories usually taken from archipelagic folklore. Even now, there is a rewriting of folklore in various regions in Indonesia. The folklore rewriting program intention is to re-socialize folklore to readers, especially the younger generation. This process is also taken as a strategy for passing on folklore to the younger generation. The most important thing from the folklore inheritance program is actually to teach values that are useful for the formation of the character of the younger generation in Indonesia.

If, in the same way, it can also be implemented widely by the Malaysian state, literary works will become a powerful tool to reconcile and create harmony between the people in both countries, especially the younger generation who are now very easily influenced by the mindset and lifestyle of Western society. The personality and mentality of the people in these two allied countries cannot equate with those in the West.

\section{Acknowledgement}

I want to thank Andalas University for providing research funding through the 2018 Professor Acceleration Scheme, contract number 41 / UN.16.17 / PP.PGB / LPPM / 2018.

\section{Bibliography}

Balckwood, Evelyn. 2001. "Representing Women: The Politics of Minangkabau Adat Writings". The Journal of Asian Studies. Vol 60, issue 2, pp. 125-149. Cambridge University Press.

De Jong, P. E, De Josselin. 1960. Minangkabau and Negeri Sembilan: Socio-Political Structure in Indonesia. Djakarta: Bhratara.

Djamaris, Edwar. 2002. Introduction to Minangkabau People's Literature. First print. 2002. Jakarta: Indonesian Torch Foundation. 
Drafting team. 2001. Second print. Indonesia Dictionary. Third edition. Jakarta: Balai Pustaka.

Elfrianto. 2015. "The Urgency of Budi Pekerti's Educational Balance at Home and School ". EduTech: Journal of Education and Social Sciences, Vol 1, (1), March $2015 . \quad$ Available: Jurnal.umsu.ac.id/index.php/edutech/article/view/266.

Gayatri, Satya. "Changes in Community Values at Carito Minangkabau Children". Salingka. vol. 14, (1), June 2017. Retrieved from https://scholar.google.com/citations?user=Xf3CyV8AAAAJ\&hl=en\#d=gs_ md_cita$\mathrm{d} \& \mathrm{p}=\& \mathrm{u}=\% 2 \mathrm{~F}$ citations $\% 3 \mathrm{Fview}$ _op $\% 3 D v i e w \_$citation $\% 26 \mathrm{hl} \% 3 \mathrm{Den} \%$ 26user\% 3DXf3CyV8AAAAJ\% 26citation_for_view\% 3DXf3CyV8AAAAJ\% 3AqjMakFHDy7sC\% 26tzom\% 3D-420.

Hara, Abubakar Eby. 2015. "Malaysia and Indonesia Relations: From Brother Serumpun to Smart Partnership". Retrieved 1 July 14, 2018, from http://www.researchgate.net/publication/281322313.

Herawan, Kadek Dedy, Sudarsana, I Ketut. 2017. "Relevance of the Value of Character Education in Geguritan Suddhamala to Improve the Quality of Education in Indonesia". Journal of Quality Assurance. Vol 3, No 2. Retrieved from http://www.ejournal.ihdn.ac.id/index.php/JPM/article/view/203. DOI: http://dx.doi.org/10.25078/jpm.v3i2.203.

Ismail, Mohd. Fahmi., Muhammad, Salmah Jan Noor., Yusop, Mohd Sharifudin. 2015. Malay Folk Story: An Analysis of the Identity of the Identity of the Malay Community as a Reflection of Malay Culture. International Journal of Language Education and Applied Linguistics (IJLEAL). Vol 3. Pp 91-100.

Indonesia Dictionary. 2010. The meaning of the words Budi and Pekerti. Retrieved 14 July 2018 from http://kbbi.web.id.

Junus, Umar. 1994. Kaba: An-Unfinished (His-)Story. Japanese Journal of Southeast Asian Studies, vol 32, issue 3, pp 399-415. Japan: Kyoto University.

Kamaruddin, Syamsu A., 2012. "Character Education and Students Social Behavior". Journal of Education and Learning. Vol.6 (4) pp. 223-230.

Law of the Republic of Indonesia number 20 of 2003. National Education System. Retrieved from https://kelembagaan.ristekdikti.go.id/wpontent/uploads/2016/08/UU_no_20_th_2003.pdf.

Lewa, Inriati. 2015. Sinrilik Kappalak Tallumbatua: Text Edits, Values, Functions, and Receptions. Available: 
http://etd.repository.ugm.ac.id/index.php?act=view\&buku id=84202\&mo $\mathrm{d}=$ penelitian detail\&sub=PenelitianDetail\&typ $=\mathrm{html}$

Liow, Joseph Chinyong. The politics of Indonesia-Malaysia relations: one kin, two nations. 2004. New York, Routledge Curzon. Available: https://scholar.google.com/scholar?hl=en\&as sdt=0\%2C $5 \& q=L i o w \% 2 C+I$ oseph+Chinyong.+The+politics+of+IndonesiaMalaysia+relations $\% 3 \mathrm{~A}+$ one + kin $\% 2 \mathrm{C}+$ two + nations. $+2004 .+\mathrm{New}+$ York $\% 2$ C+Routledge+Curzon.\&btnG $=$

Luxemburg, Yan van, et al. 1984. Introduction to Literature. Jakarta. Gramedia.

Nucci, Larry., Narvaez, Darcia., Krettenauer, Tobias (Eds). 2014. Handbook of Moral and Character Education. 2nd edition. (pp 48-49). New York and London: Routledge.

Radzi, Saiful Bahri Md. 2015. The Tanggang Moden and Meaning Change in Derhaka Patterned Children's Stories. Malaysian Journal of Communication. Vol 31, (2). pp 247-261.

Rosa, Silvia. "Transformation Form of Folktale To Be Creative Writing As Capital Formation of National Character". 2017. Proceedings of the International Conferences Language, Literature. Retrieved 25 October 2018, from http://repo.unand.ac.id/5341/.

Salehuddin, Khazriyati. 2012. "Assessment of Cognitive Complexity in the Process of Reading Jawi". Gema Online Journal of Language Studies. vol 12, (4), pp 1179 - 1192. Kualalumpur: UKM Press.

Sinaga, Johandi. 2016. "The Meaning and Meaning of the Toba Batak Community: An Overview of Literary Reception". Retrieved from http://repository.usu.ac.id/handle/123456789/56475

Suhartono, Bambang Yulianto \& Anas Ahmadi. 2010. "Folk Story on Mandangin Island: Structural Study of LevStraussss Anthropology". Journal of Airlangga University, Vol. 23, (4). Retrieved from http://www.journal.unair.ac.id/filerPDF/06_REVISI-

Cerita\%20Rakyat\%20di\%20Pulau\%20Mandangin_EDITAN\%20_tyas_\%2 0mda.pdf.

Sutjipto. "Character Education in the Primary School Curriculum. 2014". Journal of Education and Culture. Jakarta: Research and Development Agency of the Ministry of Education and Culture. Vol.20, (24). 
Suwartini, Iis,. Merawati, Fitri. 2018. The Coastal Culture of the People of Indonesia and Malaysia the Folklore Malin Kundang and Si Tanggang. Wol2SED 2018, December 21-22, Solok, Indonesia. Copyright ( 2019 EAI. DOI 10.4108/eai.21-12-2018.2282576

Wellek, Rene \& Austin Warren. 1989. Literary Theory. [translated by. Melani Budianta] Jakarta: Gramedia.

Date Received: 25 August 2019 Date of Acceptance: 15 December 2019 